\title{
Growth and Status Stock, of The Sardine Sardina Pilchardus (Walbaum, 1792) Among the Moroccan Atlantic Center-Case of Agadir Bay
}

\author{
Abdelaziz Mounir ${ }^{1 *}$, Mohammed Znari ${ }^{1,2}$, Nawal Hichamii ${ }^{1}$ and Safaa Bendami ${ }^{1}$ \\ ${ }^{1}$ Department of Biology, Cadi Ayyad University, Morocco \\ ${ }^{2}$ Research Centre on Biodiversity, Cadi Ayyad University, Morocco
}

Submission: April 06, 2020; Published: August 03, 2020

Corresponding author: Abdelaziz Mounir, Laboratory water and biodiversity and climate change, Department of Biology, Faculty of Sciences, Semlalia, Cadi Ayyad University, Marrakech, Morocco

\begin{abstract}
The objective of the present study being to study the biology and the exploitation of the sardine Sardina pilchardus fished at the level of the region of Agadir. The study of biology was approached by analyzing the growth and reproduction of the species. The study showed the importance of the landings of sardine (fish of great commercial value). Knowledge of these parameters is essential for a good analysis of population dynamics and for rational and sustainable management of these stocks. The growth study has shown that sardines are fast growing and have a short shelf life. Differential growth between males and females has been observed. The study of the linear growth of combined sex sardines and the model of Von Bertalanffy, revealed that: the growth coefficient " ' $\mathrm{k}$ ' 'is 0.311 . The asymptotic length $\mathrm{L}^{\infty}$ is $226.402 \mathrm{~mm}$. Sardines are multiple spawners that spawn several times during the same breeding season. It is noted that the sex ratio is in favor of the males and it seems that the sexual cycle, the size and the geographical distribution are the essential factors which control the variations of the sex ratio in sardines. The large individuals are generally females and the size at first sexual maturity in sardine females has been estimated at L50 = $131.33 \mathrm{~mm}$ in total length.

Kewords: Population dynamic; Linear growth; Sex ratio; Asymptotic length; Sardina pilchardus
\end{abstract}

\section{Introduction}

Given the extent of its coastline $(3500 \mathrm{Km}$ of coastline), its exclusive economic zone of more than 1.1 million $\mathrm{km} 2$ and the diversity of its marine resources, Morocco has a real fishery production potential, which can make the sector of the is an engine of economic and social development in the country. In 2016, the landing of small pelagic reached 881.489 million dirhams against 615.089 million dirhams a year earlier, an increase of $43 \%$ in value and $52 \%$ in weight, notes the ONP in its recent statistics. For a rational exploitation of these resources, assessments of their stocks and the determination of their state of exploitation are essential. To do this, basic biological studies are necessary. It is in this context that our study of the biology and exploitation of the sardine (Sardine pilchardus) landed by fishing in the port of Agadir comes into play. This species was chosen because of its economic importance and the fact that it is the main species of small pelagic fish landed by fishing.

Our modest work therefore consists in the study of certain biological parameters of sardine, such as growth and reproduction.
This study is carried out according to a regular biological sampling program, commercial catches of purse seiners landing at the port of Agadir. In addition to these biological sampling operations, data on fishing effort and landing statistics are collected from administrations involved in the fishing sector at the port of Agadir. This study was carried out at the fishery resources laboratory at the INRH Regional Center in Agadir, as a reception laboratory.

\section{Materials and Methods}

\section{Sampling}

During a period of six months, from January to June 2017, biological sampling operations were carried out regularly at the sampling station of the port of Agadir and at the rate of two to three times a week. Size measurements are then made to the bottom centimeter, using an actometer to determine the size distribution of the Sardine landed by the inshore fishery. Then, a subsample is taken to collect the other parameters relating to the biology of the sardine. For everyone in the sub-sample, the 
total length is measured to the nearest millimeter while the body weight is taken to the nearest gram using a precision balance.

The fish are then dissected to determine their sex and stage of sexual maturity. The gonads and the liver are removed and weighed to the nearest $0.01 \mathrm{~g}$. The otoliths are kept in resin plates for age reading. During our study, we used the resources of the Fisheries Resources laboratory of the Regional Center of the National Fisheries Research Institute in Agadir which consist of Precision electronic balance to within $0.01 \mathrm{~g}$; Ichthyometer; Dissection kit; Bin Binocular magnifier with monitor.

\section{The Growth}

In fish, age measurement can be done using two methods:

- The methods of individual determination which give the age of an individual from a natural or experimental mark.

- $\quad$ Collective determination methods which statistically give the average age of a group of individuals or the most likely age of an individual of given size [1].

The examination of calcified parts is the most used method. Three main types of pieces have been found to carry information scalimetry, which deals with scales, otolithometry, otoliths, and skeletochronology, bones, then were the first to hypothesize that the concentric ridges of the surface of the scales correspond to the different stages of fish growth. Given the difficulty of analyzing scales in certain species, or the absence of this in other species, scientists turned to other calcified parts. Thus, the analysis of otoliths developed at the end of the 19th century based on the work of Reibisch. In sardines, age estimation seems easier and more reliable with otoliths [2].

\section{Description and Function of Otoliths}

An otolith, from the Greek otos-ear and lithos-stone, is a calcareous concretion present in the inner ear; they are housed in chambers (respectively utricle, saccule) which connect the semicircular canals. Otoliths are receptors involved in acoustic processes and in the spatial perception of fish [3-6] and they participate in the maintenance and regulation of muscle tone [7]. Each fish has 3 pairs of otoliths, lapilli, astericus and sagittae. The latter are the largest and are most often used to interpret the age of bony fish [8]. The sagittae of each species has its own form and growth rate which characterize it [9].

\section{Otolith Removal and Conservation}

The otoliths used for the determination of age are those of the pair "" sagitae ". They are housed in the saccule of the inner ear. They are extracted after a cut of the head, practiced at the limit of the upper edge of the operculum or by removal of the gill apparatus and perforation of the capsules. After removal, the otoliths are cleaned with clean water by carefully rubbing them between the fingers. Once dry, these are fixed with resin in blackbottomed plates to facilitate both conservation and reading.

\section{Interpretation of Rings and Age Allocation}

Examination of the entire otolith (lit from above on a black background) shows a series of alternately light and dark rings. These rings come from a limestone deposit in the form of opaque zones and hyaline zones during an annual growth cycle of the otolith. They are located between the center (nucleus) and the outer edge of the otolith (Figure1). The age of a fish is determined by counting the number of opaque or translucent (hyaline) rings visible on an otolith, lit by reflected light. To visualize the growth rings on the surface of the otolith, we use a stereoscopic magnifier equipped with a camera system which is connected to a computer with an image analysis program which also makes it possible to take the measurements between the different growth rings and the nucleus. When reading the otoliths, reliability indices are assigned according to the degree of confidence in the reading:

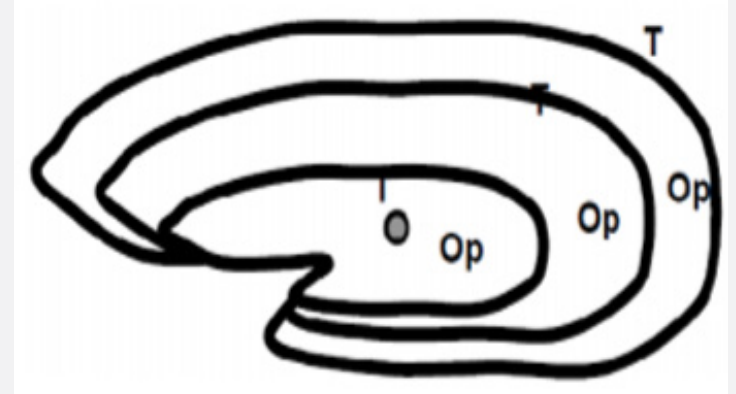

Figure 1: Example of an otolith (Op: Opaque and T: Translucent).

\section{Determination of Age-size keys}

Direct monthly reading of the otoliths made it possible to obtain value pairs (âgetaille) and to establish age-size keys by sex for all the individuals sampled. The ages are estimated in years.

\section{Linear Growth}

In population dynamics, the model of Von Bertalanffy [11] is chosen to mathematically express linear growth. This model is adjusted as well from the age of recruitment as from that at 
the first capture. In addition, it is the easiest to integrate into production equations [12]. His expression is $L t=L_{\infty}\left(1-e^{-k\left(t-t_{0}\right)}\right)$

with,

Lt: Length of fish at time $t$ (in years).

$L^{\infty}$ : Asymptotic length that a fish would expect at the infinite theoretical age. L should not be systematically confused with the maximum size reached by the fish.

$\mathrm{k}$ : Coefficient representing the metabolism of fish. It is the slope of adjustment between the size and the instantaneous increase of the size. In the derivative, $\mathrm{k}$ fixes the mode of reduction of the growth rate as the size grows.

t0: The theoretical age for which the fish would have a zero size (the curve cuts the abscissa axis), or at birth, the larvae or the juveniles already have a length which is not zero.

Two remarks are in order:

The parameters $\mathrm{L} \infty, \mathrm{k}$ and to are only purely mathematical values, the biological reality of which is not systematic. $L t+(\Delta t-L t)=(L-L t) .\left(1-e-^{k \Delta t}\right)$ The value of two is estimated from the logarithmic transformation of Von Bertalanffy's equation: The value of two is estimated from the logarithmic transformation of Von Bertalanffy's equation: ( $\mathrm{L}-\mathrm{Lt}) / \mathrm{L}=\mathrm{e}-\mathrm{k}(\mathrm{t}-\mathrm{to})$ where $\ln ((\mathrm{L}-$ $\mathrm{Lt}) / \mathrm{L})=-\mathrm{k}(\mathrm{t}-\mathrm{t} 0)$

$$
\mathrm{t} 0=\mathrm{t}+(1 / \mathrm{k}) \cdot(\ln ((\mathrm{L}-\mathrm{Lt}) / \mathrm{L})
$$

When $\mathrm{Lt}=0$, the time $\mathrm{t} 0=\mathrm{t}$

t0 is calculated for each age group, the t0 used being the average of all the estimated to.

\section{Size-weight Relationship}

In most fish, there is an allometric relationship between fish size and weight [7]. This relationship is influenced by the availability of food, the development of the gonads and reproduction [13]. It is widely used in fishing biology to estimate the modifications that growth can cause on the morphology of the species. It also makes it possible to follow, depending on the size, the changes in sex and the maturity of the gonads. It is translated by an equation of type: $\mathrm{W}=\mathrm{aLb}$

with, W: Weight of fish.

$$
\begin{aligned}
& \text { L: Total length of the fish. } \\
& \text { a: Constant. } \\
& \text { b: coefficient of allometry. }
\end{aligned}
$$

determination of $a$ and $b$ is done by the method of reduced major axes after logarithmic transformation of the above power function: $\log W=\log a+b \log L$.

Depending on the species, the allometric coefficient $\mathrm{b}$ can be between 2.5 and 4 [1,10]. $\checkmark \quad$ If $\mathrm{b}$ is equal to 3 , the growth is isometric: the gains in weight and length are proportional.

$\checkmark \quad$ If $\mathrm{b}$ is different from 3 , there is allometry (lower if $\mathrm{b}<3$, higher if $b>3$ [4]).

\section{Weight growth}

The weight growth equation is obtained by combining the linear growth equation and the height-weight relationship. In this case the equation of Von Bertalanffy, is written according to Guilland: $\mathrm{Wt}=\mathrm{W}(1-\mathrm{e}(-\mathrm{k} *(\mathrm{t}-\mathrm{to})) \mathrm{b}$

Wt: weight at time t.

$\mathrm{W}$ : $\mathrm{aLb}$; $\mathrm{a}$ and $\mathrm{b}$ being the parameters of the size-weight relationship. $\mathrm{k}$ and to are the linear growth parameters.

\section{Reproduction}

Reproductive biology was studied through the analysis of the gonads and the determination of the state of sexual maturity of the sardine. This study allowed the calculation of the sex ratio, the determination of the laying period and the size at the first sexual maturity.

\section{Sex-ratio}

The sex ratio is a parameter which makes it possible to assess the demographic structure and the fertile biomass of the stock [4]. It is the proportion of males and females in the sample. It is calculated as follows:

$\%$ males $=(\mathrm{n} 1 / \mathrm{N}) * 100$ and $\%$ females $=(\mathrm{n} 2 / \mathrm{N}) * 100$

with, N: Sample size, n1: number of male individuals, n2: number of female individuals

The evolution of the sex ratio was carried out by month and by size class.

\section{Maturity Stages}

The determination of the stage of sexual maturity was carried out macroscopically using a scale of sexual maturity composed of five stages.

\section{The Gonado-Somatic Index (GSI)}

The monthly evolution of gonado-somatic index makes it possible to determine the laying period. These two ratios are calculated by the following relation: \% GSI $=(\mathrm{Pg} / \mathrm{Ps}) * 100$

with, Pg: gonad weight (in grams) Ps: somatic weight (full weight or eviscerated weight) (in grams).

\section{The First Sexual Maturity L50}

Several definitions are given of size at first sexual maturity; those most often accepted are:

The size of the smallest mature individual or the largest immature individual during the breeding season 
The length for which $50 \%$ of individuals in a population are sexually mature during the breeding period. These two definitions have been retained in this study. The determination of the L50 (length from which $50 \%$ of the fish are mature) was made by grouping the individuals sampled during the main breeding season, by sex and by size class. Next, the proportion of mature individuals in each size class was calculated. The sexual maturity threshold is fixed at stage III which corresponds to the beginning of the gonad development phase [14]. The size-proportion pairs of mature individuals are adjusted to a logistic curve of the symmetric sigmoid type $[10,15]$ whose mathematical expression is as follows:

$$
P=1 /(1+e-(a+b * L))
$$

with, P: Proportion of masts by size class L: Total length a: Originally ordered b: Slope

The parameters a and b are obtained, after the logarithmic transformation of expression (1), by the method of least squares.

$$
\operatorname{Ln}(P /(1-P))=a+b * L
$$

The representation of the maturity ogive is made by considering all the pairs of values except those which have a proportion: $\mathrm{P}=0$ and $\mathrm{P}=1 . \mathrm{L} 50=-\mathrm{a} / \mathrm{b}$

The age of first sexual maturity is then deduced using the growth model established on sardines.

\section{Exploitation}

\section{Fishing area}

For the determination of the fishing zones and their characteristics, a questionnaire was established to carry out surveys near the fishing bosses during the landings.

\section{Demographic Study}

This study was made on the frequency distribution of sizes. It will allow us to understand the demographic structures of the species and to have an image on exploited populations and the level of their recruitment which can give some clues on the state of exploited stocks. The size frequency distribution was established from the size measurement data which were weighted when the vessel was caught and then added class by class $0.5 \mathrm{~cm}$ lower than the other distributions obtained during the month. This sum is then raised to the total monthly catch declared at the port.

\section{Stock Status}

\section{Determination of the Size at First Capture (LC)}

According to CADDY, the curve of the natural logarithm of the numbers ( $\mathrm{Ln} \mathrm{N}$ ) as a function of the size (L) shows a descending part. This part is used to determine (Lc). By plotting the line which corresponds to the natural logarithm of half of the numbers, we obtain a curve parallel to the descending part. The intersection of this line with the left part of the curve gives the value of (Lc).

\section{Total Mortality Estimate, by Fishing and Natural}

In fisheries biology, the most useful way to express the decrease in number of fish in an age group over time is to use exponential rates of decrease. These rates, three in number, are defined by the following two expressions: $N t=N o \cdot e^{-Z t}$ with; No $=$ initial number of fish at time to, $\mathrm{Nt}=$ number of fish surviving at time $\mathrm{t} \mathrm{Z}=$ exponential rate of total mortality, one advantage of exponential rates is that they can be added or subtracted; we thus have: $\mathrm{Z}=\mathrm{M}+\mathrm{F}$

with $\mathrm{M}=$ exponential rate of natural mortality $\mathrm{F}=$ exponential rate of fishing mortality

Regarding mortalities, we must: Estimate the value of Z; Break down, if necessary, the estimated value of $\mathrm{Z}$ into its two components $\mathrm{M}$ and $\mathrm{F}$.

\section{Estimated Total Mortality}

Estimated total mortality from the mean size in the catch. When many size frequency data have been obtained for a given stock and for a given fishing gear, $\mathrm{Z}$ can be estimated from the average length of the catch in each population using the relationship: $\mathrm{Z}=\mathrm{K}(\mathrm{L} \infty-\mathrm{Lm}) /(\mathrm{Lm}-\mathrm{L})$, Relation in which $\mathrm{L} \infty$ and $\mathrm{K}$ are the parameters of Von Bertalanffy's growth equation, is the average length of the fish caught, and $L$ is the first size from which all the fish in a sample have an equal probability the unit to be retained by the fishing gear.

\section{Stock Status Estimation}

The exploitation rate (E) determines the proportion taken by fishing. It thus allows us to know the state of the stock (equilibrium, over or under exploited) The stock is in equilibrium if $\mathrm{E}$ is close to 0.5 is itself based on another assumption, namely that the potential balanced catch is optimized when $\mathrm{F} \approx \mathrm{M}$. The exploitation rate is deducted using the relationship below: $\mathrm{E}=$ $\mathrm{F} / \mathrm{Z}=\mathrm{F} / \mathrm{M}+\mathrm{Z}$

With: F: fishing mortality M: natural mortality Z: total mortality E: exploitation rate.

\section{Results and Discussion}

The GROWTH the minimum and maximum age classes observed are 1 to 3 years respectively for both sexes. Male and female sardines are numerous in the 2- and 3-year age groups. The estimation of individual age allowed us to determine the average sizes of individuals according to their sex and for all the sardines sampled in the study region. We then adjusted the equation of the Von Bertalanffy model to the pairs of mean agelength values calculated on all individuals, on males and females separately. The comparison of the growth curves in length of the sardines established for each sex and combined sex shows that the females have a higher growth than the males and thus reach a final size (Lo: infinite size) greater than that of the males. 
Von Bertalanffy's equations expressing linear growth as a function of time for the different sexes: - Combined sex: $L t=226.40 *(1-e(-0.311 *(t+2.18)))$

$$
\begin{aligned}
& \text { - Female : } L t=225.57 *(1-e(-0.350 *(t+1.87))) \\
& \text { - male : } L t=205.46 *(1-e(-0.369 *(t+
\end{aligned}
$$

Size-weight relationship

The size-weight relationship is widely used in fishing biology to estimate the modifications that growth can cause on the morphology of the species. In addition, it makes it possible to calculate the probable weight of a fish of a given size and to transform the growth equation in length into a growth equation in weight. Statistical comparison of the equations reveals whether the possible differences in weight according to sex lie at the level of the slope (b) or the position (a) of the regression lines. When the differences between the parameters (a) and (b) of the relationships are not significant, the data are grouped.

\section{Height-Weight Relationship by Sex}

Height-weightrelationships were established separately by sex for all the samples taken during our study period. The correlation coefficient is high in both sexes and shows a strong correlation between weight and height. The coefficient of allometry (b) is significantly greater than 3 , it indicates an increasing allometry in both sexes. As a result, the sardine presents an increase in weight proportionally greater than its growth in size. The size-weight relationships for the different sexes are therefore: Female sardine: $\mathrm{Pt}=0.00004$ Lt 3.12 Male sardine: Pt $=0.00003$ Lt 3.19 With Pt: total weight, Lt: total length, The combination of the height-weight relationship and the Von Bertalanffy equation made it possible to establish the weight growth equations by sex.
The equations obtained are valid in the age range from 1 to 3 years:

$$
\begin{gathered}
\text { - } \begin{array}{l}
\text { Sexes } \\
W t
\end{array}=93.59 *(1-e(-0.31 *(t+2.18)) 3.12 \\
\text { - } \quad \text { Males : } W t=70.59 *(1-e(-0.36 *(t+1.62)) 3.18 \\
\text { - } \quad \text { Females: } W t=87.26 *(1-e(-0.35 *(t+1.88)) 3,11
\end{gathered}
$$

Graphical representations of weight growth revealed differences in growth between males and females from the first year of life. Weight gains are more marked in females. The difference in weight between males and females of one year reaches $5 \mathrm{~g}$. However, this difference in weight in favor of females increases with age and weight gain becomes identical for both sexes at five years of age. Concerning some reproduction parameters, we distingue that the sex ratio is generally in favor the males, whereas the evolution of the sex ratio by size class in sardines showed us a dominance of large females and small males.

\section{Monthly Evolution of the Average Gonado-Somatic Index}

The average GSI of males and females evolve in the same way during our period. The peaks in mean RGS of males and females occur in January (males: 0.070 and female: 0.073 ) and in May (males: 0.019 and female: 0.020 ).

\section{Exploitation}

National production of Sardine Production in small pelagic during the period 2006-2016 is variable, reaching a peak of nearly $1,089,144.5$ tons in 2016. The average catch during the last five years is around 900,000 tons (Figure 2). Sardine represents the first species caught in the Moroccan zone. Over the past five years, it has averaged $65 \%$ of the catch.

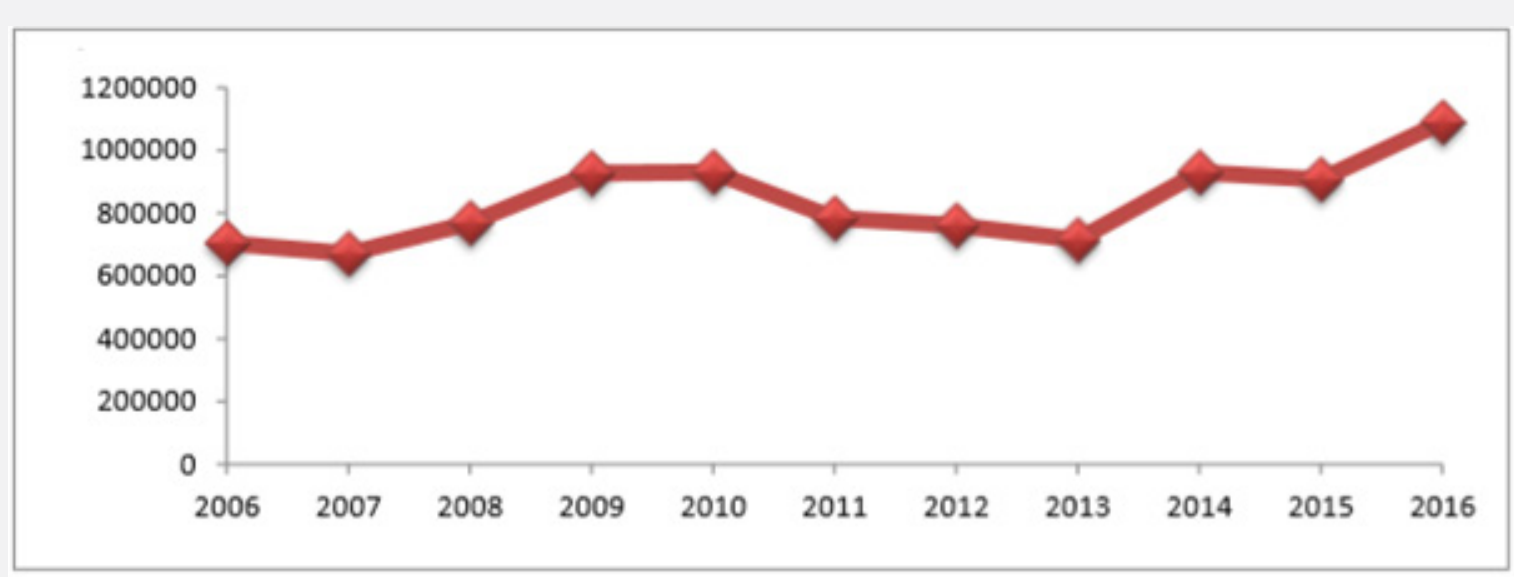

Figure 2: Evolution of the production of sardines in morocco.

\section{Fishing effort}

The evolution of the fishing effort, applied to the sardine, is proportional to that of the monthly landings. In fact, the greatest effort was observed in March, which corresponds to the highest amount of sardine, i.e. for the entire fleet studied, a total of 440 working days for a landing of 3223 tons of sardine. The minimum 
effort is observed in May with 257 working days corresponding to a weight of 3223 tons of sardines.

\section{Stock status}

\section{Size at first capture}

The size at first capture is expressed in terms of the total length. It corresponds to 15.2 in the Agadir region. The age corresponding to this size obtained from the VON BERTALLANFY curves is 1 year.

\section{Mortality Estimate and Exploitation Rate}

The total monthly mortality shown below shows that mortality increases in January and March, which coincides with the breeding period (Table 1,2).

Table 1: Total monthly mortality of Sardina pilchardus at the port of Agadir from January to May 2017.

\begin{tabular}{|c|c|c|c|c|c|}
\hline Letter name & January & February & March & April & June \\
\hline M & 1.626752901 & 0.879068987 & 2.029739038 & 0.679669562 & 0.69455314 \\
\hline
\end{tabular}

Table 2: Mortality coefficients and exploitation rate of Sardina pilchardus at the port of Agadir from January to May 2017.

\begin{tabular}{|c|c|c|c|c|}
\hline & $\mathbf{Z}$ & $\mathbf{M}$ & $\mathbf{F}$ & E \\
\hline Agadir & 0,3199 & 1,18195516 & 0,70615516 & 59,75 \\
\hline
\end{tabular}

\section{Discussion}

The maximum age of sardines does not exceed three years in the Agadir area. Indeed, Scherbitch found that in the Atlantic coasts of Morocco, the maximum age of sardines does not exceed 5 to 6 years and that the catches consist mainly of fish aged 2 to 3 years. While, the minimum age is zero. When compared by sex, females are more asymptotic in length and weight than males. A similar result has been observed in other sardine populations in other geographic areas $[3,16,17]$. The comparison of the parameters of Von Bertalanffy (Lo, k) in S. pilchardus of Agadir shows are higher than those found compared to those obtained in different regions, this is represented in table.

This can be explained by the difference maximum sizes sampled in the different regions or by observed differences due to the heterogeneity of the methods used such as direct reading on otoliths or scales, reverse calculation, size frequency analysis, individual cohorts or cohorts synthetic or the reading of age which is not uniform or by the existence of a very favorable environment for the development of sardines in the area concerned, probably due to the temperature since the average annual temperature recorded in the area study temperature is $22^{\circ} \mathrm{C}$. This is higher than the temperatures noted in other zones. For example, we note $18^{\circ} \mathrm{C}$ for the Adriatic and $20^{\circ} \mathrm{C}$ for the North-West Mediterranean. Lagardère [1] demonstrated the thermophilic tendency of this species which prefers water at optimal temperature.

The overall sex ratio of sardines landed in the port of Agadir showed a dominance of males over females. This dominance can be explained by the fact that the spatial distribution of the two sexes is not identical. On the other hand, this dependence on the distribution of the sex ratio as a function of height, indicating a high rate of femininity at large sizes, has been mentioned by Lee [18], Bouchereau [3], Belvèze [4], Amenzoui et al., [17] and by Khemiri [16]. This biological characteristic seems to be a general rule in Clupeiformes because it has been observed in other species such as flat sardinella, Sardinella maderensis sardinella from Venezuela round sardinella Sardinella aurita [8,13].

The strong femininity of large classes may be the result of the influence of several factors, the most plausible of which would be greater longevity and faster growth of females, greatervulnerability to fishing gear or still migratory movements different from those of males. During the six months of the study, the evolution of the RGS showed that the laying period could take place between January and March, indeed this period is characterized by a high maturity of the female gonads. The histological study confirms the reproductive period which was determined by the RGS in S. pilchardus; these results are comparable to those reported by Pinto and Andreu and modified by Mouhoub. Along the Algerian coasts, S. Plichardus generally reproduces in the same period: Algiers coasts and Orannaises [19], from December to March and Annaba Bay between January and March [20].

On the Atlantic coasts, the size at first sexual maturity estimated for the female and male sardines landed at the port of Agadir, is 131 even in females. Several studies carried out on pruning at the first maturity of sardines show the differences in maturation from one region to another. Khemiri in 2006 found almost similar values on the Tunisian coasts with an L50 = 113 $\mathrm{mm}$ for both sexes [21], found an L50 = $172 \mathrm{~mm}$ in the Bay of Biscay, the same authors in 2006 reported an L50 $=168 \mathrm{~mm}$ in the North of France and an L50 $=146 \mathrm{~mm}$ in the North of Portugal, while Mendez -Villamil Mata et al. [22] mentioned L50 = $152 \mathrm{~mm}$ in females and $150 \mathrm{~mm}$ in males in the Canary Islands finally, in the Laâyoune Region Amenzoui et al., [17] measured an L50 = 158 $\mathrm{mm}$ for both sexes [23-27].

The total tonnage of sardines landed at the port of Agadir in 2016 represents $42.3 \%$ of the pelagic fish in this port [28-30]. In 2017, and during the period between January and May, these landings reached 19.8\%. Most of these landings come from Sidi Ifni, followed by Agadir. Indeed, the large width of the continental 
shelf, the low spawning, and the sandy-muddy bottoms in the two regions of Sidi Ifni and Agadir favor the abundance of landing areas. This explains the large catches of sardines in this region [31-35]. The sardine landings observed at the port of Agadir, in February, are the highest during the first five months of 2017, with a tonnage of 4,900 tons. This could be due to a high fishing effort applied to the sardine in this month [36-39].

The exploitation rate determined for the Agadir region is 59.75 which means that the stock is fully exploited [40-42]. This means that the young recruits are heavily sinned, the average sizes are always less than the size of the first sexual maturity and the laying period coincides with a strong exploitation of adults. In the light of this modest work, it is recommended to carry out more indepth studies over longer periods and to tackle other aspects such as the daily reading of otoliths, the localization of spawning areas and multidisciplinary studies essential for better understand the dynamics of stocks of this species to ensure better management for sustainable economic exploitation.

\section{References}

1. Daget J, Le Guen J C (1975) Dynamique des populations exploitées de poissons. In : Lamotte $M$, Bourlière $F$ (Eds.). Problèmes d'écologie : la démographie des populations de vertébrés, Masson et Cie, Paris, Pp : 395-443.

2. FAO (1997) Rapport du groupe de travail ad hoc sur la sardine. COPACE/PACE SER 97(61): 164.

3. Bouchereau J L (1981) Contribution à l"étude de la biologie et de la dynamique exploitée de Sardina pilchardus (Walbaum, 1792) dans la baie d"Oran (Algérie). Thèse Doctorale 3ème cycle, Univ. Aix-Marseille II.

4. Belvèze H (1984) Biologie et dynamique des populations de sardine (Sardina pilchardus) peuplant les côtes atlantiques et proposition pour un aménagement des pêcheries, Thèse d"Etat, université Brest Occidentale $\mathrm{p}: 531$

5. Fréon P (1988) Réponses et adaptations des stocks de clupéidés d"Afrique de l"ouest à la variabilité du milieu et de l"exploitation : Analyse et réflexion à partir de l"exemple du Sénégal. Inst Française de Recherche Sci pour le développement en Coopération 287.

6. Allain V (1999) Ecologie, biologie et exploitation des populations de poissons profonds de l'Atlantique du Nord-Est. Thèse de Doctorat de l"Université de Bretagne Occidentale 373.

7. Furnestin ML (1957) Chaetognathes et zooplancton du secteur Atlantique marocain. Revue des Travaux de l'Institut des Pêches Maritimes 21(1-2) : 1-356.

8. Gaamour A (1999) La sardinelle ronde (Sardinella aurita, Valenciennes, 1847) dans les eaux tunisiennes. Reproduction, croissance et pêche dans la région du cap Bon. Océanographie biologique. Thèse de Doctorat d'Etat. Université de Bretagne occidentale.

9. FAO (1985) Rapport de la troisième réunion du groupe de travail ad hoc sur Sardina pilchardus (Walb). COPACE/PACE SER 85(39) : 157.

10. Benazzouz A, Hilmi K, Orbi A, Demarcq H, A Atillah (2006) Dynamique spatiotemporelle de l'upwelling côtier marocain par télédétection de 1985 à 2005. Géo- Observateur 15 : 15-23.

11. Von Bertalanffy L (1938) A quantitative theory of organic growth (inquiries on growth laws II). Human biology 10(2): 181-213.
12. Daget J, JC Le Guen (1975) Les critères d'âge chez les poissons. In : Lamotte $M$, Bourlière $F$ (Eds.). Problèmes d'écologie : la démographie des populations de vertébrés, Masson et Cie, Paris, P. 443.

13. Fréon P (1979) Relation taille-poids, facteur de condition, et indice de mortalité sexuelle: rappels bibliographiques, interprétations, remarques et applications. CRODT 68 : 144-171.

14. FAO (1978) Les pêches dans l"Atlantique Centre-Est. In : Rapport du groupe de Travail sur l"unification de la détermination de l"age de la sardine (Sardina pilchardus walb.). COPACE Rapport tech, Dakar, Senegal P. 8.

15. Anderson and S Gutreuter (1983) Length, weight and associated structural indices Fisheries techniques. In: Nielsen L, Johnson D (eds.) American Fisheries Society, Bethesda, Maryland, US, Pp : 283-300.

16. Khemiri S (2006) Reproduction, AGA et croissance des trois espéces de téléosteens pélagiques des côtes tunisiennes: Engraulis encrasicalus, Sardina pilchardus et Boops loops. Thése doctorat de l"ENSAR Ecole Nationale Superieure Agronomique de Rennes Spécialité Halieutique.

17. Amenzoui k, F Ferhan-Tachinante, A Yahyaoui, S Kifani, A Mesfioui (2006) Analysis of the cycle of reproduction of Sardina pilchardus (Walbaum, 1792) off the Moroccan Atlantic coast. Comptes Rendus Biologies 329(11) : 892-901.

18. Lee JY (1962) La sardine du golf du lion (Sardina pilchardus sardina Regan). Thèse Fac. Sci. Paris $3862: 102$.

19. Tomasini JA, JL Bouchereau, A Ben Sahala Talet (1989) Reproduction et condition chez la sardine (Sardina pilchardus Walbaum, 1792) des côtes oranaises (Algérie). Cybium13(1): 37-50.

20. Chlaïda M (2009) Variabilité allozymique associée au flux migratoire des populations de sardine, Sardina pilchardus, le long des côtes NordOuest africaine. Thèse de Doctorat, Université Mohammed V Rabat, Spécialité génétique des populations, Faculté des Sciences.

21. Amenzoui L K, F Ferhan-Tachinante, A Yehyaoui, A H Mesfioui, S Kifani (2004) Etude de quelques aspects de la reproduction de Sardina pilchardus (Walbaum, 1792) de la région de Lâayoune (Maroc). Bulletin de l"Institut Scientifique, Rabat, section Sciences de la Vie (2627) : 43-50.

22. Fréon P, M El Khattabi, J Mendoza (1997) Unexpected reproductive strategy of Sardinella aurita of the coast of Venezuela. Marine Biology 128: $363-372$

23. Amenzoui L K, F Ferhan Tachinante, A Yehyaoui, A H Mesfioui (2005) Caractéristique reproductive de la sardine, Sardina pilchardus (Walbaum, 1792) dela côte Atlantique marocaine. In: Chouikhi A, M Menoui (eds.). Marine and coastal proteced areas. International Workshop Proceedings, INOC, Morocco, Pp: 266-268.

24. Bernikov R (1991) Synthèse des travaux de recherches océanographiques réalisés le long de la côte atlantique marocaine par Atlantniro 24.

25. Berraho Am (2007) Relations spatialisées entre milieu et ichtyoplancton des petits pélagiques de la côte atlantique marocaine (zones centrale et sud). Thèse Doc. Univ. Mohamed 266.

26. Chlaïda M, V Laurent, S Kifani, T Benazzou, H Jaziri, etc. (2008) Evidence of genetic cline for Sardina pilchardus along the Northwest Africa coast. ICES Journof Marine Science 66 : 264-271.

27. Daget J (1972) Lois de croissance linéaire et pondérale, Mortalités, Structures démographiques. Modèles linéaires de Shaefer et modèles exponentiels de Fox ORSTOM $28: 58$

28. Dobrovine B, Mahfoud M, Dedah S (1991) La ZEE mauritanienne et son environnement géographique, géomorphologique et hydroclimatique. 
29. Ettahiri O (1996) Etude de la phase planctonique de la sardine, Sardina pilchardus (Walb.) et de l'anchois, Engraulis encrasicolus (L.) des côtes atlantiques marocaines, Thèse Doctorat Océanographie, Biologie université Bretagne Occidentale, P. 262.

30. Ettahiri O, A Berraho, G Vidy, M Ramdani, T Dochi (2003) Observation on the spawning of Sardina and European pilchardlla off the south Maroccan Atlantic coast (21-26 N). Fish Res 60: 207-222.

31. FAO (2007) Report of the FAO Working Group on the Assessment of Small Pelagic Fish off Northwest Africa. Nouadhibou, Mauritania 2227.

32. Fargo J, AV Tyler (1994) Oocyste maturation in Hetate Strait English sole (Pleuronectes vetulus). Fish Bulletin $92: 189-197$.

33. Fisher W, M Schneider, ML Bouchot (1987) Fishes FAO d"identification des espèces pour les besoins de la pêche. Méditerranée et Mer Noire -Zone de pêche 37. Vertébrés 2: 766.

34. Freudenthal T, Meggers H, Henderiks J, Kuhlmann H, Moreno A, etc. (2002) Upwelling intensity and filament activity off Morocco during the last 250.000 years. Deep Sea Research Part II: Topical Studies in Oceanography 49(17): 3655-3674

35. Furnestin J (1945) Contribution à l"étude biologique de la sardine
Atlantique (Sardina pilchardus Walbaum). Revue des Travaux de l'Institut des Pêches Maritimes $13: 221-386$.

36. Furnestin J (1950) Premières observations sur la biologie de la sardine marocaine. Rapp P V Réun Cons Perm Int Explor Mer 126 : 57-61.

37. Furnestin J (1952) Biologie des clupéidés méditerranéens. Vie et Milieu 2 : 96-117.

38. Furnestin J (1959) Hydrologie du Maroc Atlantique. Revue des Travaux de l'Institut des Pêches Maritimes 23(1) : 5-77.

39. Furnestin J \& ML Furnestin (1970) La sardine marocaine et sa pêche. Migrations trophique et génétique en relation avec l"hydrologie et le plancton. Rapp PV Réun Cons int Explor Mer 139 : 165-175.

40. Furnestin M L (1976) Les copépodes du plateau continental marocain et du détroit canarien. I. Répartition quantitative. Con Int Explor Mer $8: 22-46$.

41. INRH (2002) Les ressources halieutiques marocaines : situation et niveaux d"exploitation. Doc Tech INRH 167.

42. Makaoui A, A Orbi, K Hilmi, S Zizah, J Larissi, et al. (2005) L"upwelling à côte atlantique du Maroc entre 1994 et 1998. Comptes Rendus Geoscience 337(16) : 1518-1524.

\section{Your next submission with Juniper Publishers} will reach you the below assets

- Quality Editorial service

- Swift Peer Review

- Reprints availability

- E-prints Service

- Manuscript Podcast for convenient understanding

- Global attainment for your research

- Manuscript accessibility in different formats

( Pdf, E-pub, Full Text, Audio)

- Unceasing customer service

Track the below URL for one-step submission https://juniperpublishers.com/online-submission.php 